\title{
OUR SPACE : THE CONVERGENCE OF CULTURAL INTERACTIVE EXPERIENCES AND DISTRIBUTED INNOVATION IN MUSEUMS
}

\author{
Angelina Russo, $\mathrm{PhD}$ \\ Faculty of Design \\ Swinburne University \\ PA25, 144 High Street \\ Prahran \\ Victoria 3181 \\ Australia \\ arusso@swin.edu.au \\ http://nlablog.wordpress.com
}

\begin{abstract}
Throughout the museum sector, the notion of considering museums as integral to the innovation debate is gaining momentum. Dawson [1] suggests that the imperative to adapt and innovate is sometimes at odds with traditional ways of delivering organizational programs. In Australia, museums have historically been seen as part of the cultural heritage/ arts/ welfare sector and have, for the most part, been overlooked, or undervalued in discussions of innovation and creativity [2].
\end{abstract}

\section{SUMMARY}

Dawson [1] provides some compelling arguments to suggest that innovation requires collaboration. Three-way communication which responds to the knowledge which audiences bring with them, establishes the foundation for new models of interaction and participation. Without exploring these in structured ways, there is a chance that museums will lose the potential to lead innovation. Poulson and Kale [3] define commercial experiences as "an engaging act of co-creation between a provider and a consumer wherein the consumer perceives value in the encounter and in the subsequent memory of that encounter". While their discussion is directed toward the creation of commercial experiences, is it so far from the types of interaction and participation which we would hope to achieve in the cultural sector?

In 2008, The Museum of New Zealand, Te Papa Tongarewa launched two new permanent exhibitions which have, at their heart, co-created and user-generated content. Our Space [4] includes an 18metre projection wall where audiences load their content and create works. Following their visit, they are able to upload images which are then transferred to kiosks within the physical space and are made available for audiences to remix. The exhibition includes The Map, a large floor map of New Zealand where audience movement triggers images which appear on the mirrored media walls and glass floor. This exhibition is a significant example of the conversion from virtual usergenerated content to physical cultural interactive experiences.

The Map and Our Space are some of the first permanent museum exhibitions in the world to incorporate user-generated and co-created content and in turn, are significant 
EVA 2009 London Conference 6-8 July

Angelina Russo

examples of the innovation which museums are capable of both leading and producing. This paper uses the Te Papa example to explore notions of distributed innovation and the convergence of cultural interactive experiences. It contextualises creative audience participation and questions future opportunities.

\section{References}

[1] DAWSON, R. Living networks. Leading your company, customers, and partners in the hyper-connected economy. Lulu Press Inc., 2008.

[2] CULTURAL MINISTER'S COUNCIL. Building a creative innovation economy. Cultural Minister's Council Creative Innovation Economy Roundtable. [First accessed February 28 2008]

http://www.cmc.gov.au/publications/

[3] POULSON, S. and KALE, S. The Experience Economy and Commercial Experiences. The Marketing Review. 2004, 4, pp.267-277.

[4] OUR SPACE:

http://www.tepapa.govt.nz/TePapa/English/WhatsOn/LongTermExhibitions/Our Space.htm 